\title{
Cryptic diversity and range extension in the big-eyed bat genus Chiroderma (Chiroptera, Phyllostomidae)
}

\author{
Burton K. Lim', Livia O. Loureiro², Guilherme S.T. Garbino ${ }^{3}$ \\ I Department of Natural History, Royal Ontario Museum, 100 Queen's Park, Toronto, Ontario M5S 2C6, Ca- \\ nada 2 Department of Ecology and Evolutionary Biology, University of Toronto, Toronto, Ontario MSS 3B2, \\ Canada 3 PPG-Zoologia, Departamento de Zoologia, Instituto de Ciências Biológicas, Universidade Federal \\ de Minas Gerais, Avenida Antônio Carlos 6627, Pampulha, 31270-901, Belo Horizonte, Minas Gerais, Brazil
}

Corresponding author: Burton K. Lim (burtonl@rom.on.ca)

Academic editor: DeeAnn Reeder | Received 26 November 2019 | Accepted 28 January 2020 | Published 12 March 2020

http://zoobank.org/8C780A96-9353-4F34-8892-64822D8E2932

Citation: Lim BK, Loureiro LO, Garbino GST (2020) Cryptic diversity and range extension in the big-eyed bat genus Chiroderma (Chiroptera, Phyllostomidae). ZooKeys 918: 41-63. https://doi.org/10.3897/zookeys.918.48786

\begin{abstract}
Since the last systematic review of Chiroderma (big-eyed bats) more than two decades ago, we report on biodiversity surveys that expand the distribution and species diversity of this Neotropical genus. The Caribbean endemic species Chiroderma improvisum is documented for the first time from Nevis in the northern Lesser Antilles. A broader geographic sampling for a molecular analysis identifies a paraphyletic relationship in Chiroderma trinitatum with respect to Chiroderma doriae. Cis-Andean populations of $C$. trinitatum are most closely related to the morphologically distinctive and allopatrically distributed $C$. doriae in the Cerrado and Atlantic Forest of Brazil and Paraguay. The sister taxon to this grouping includes trans-Andean populations of $C$. trinitatum, which we recommend to elevate to species status as $C$. gorgasi. This is an example of a cryptic species because $C$. gorgasi was previously considered morphologically similar to $C$. trinitatum, but more detailed examination revealed that it lacks a posterolabial accessory cusp on the lower second premolar and has a narrower breadth of the braincase. We provide an amended description of Chiroderma gorgasi.
\end{abstract}

\section{Keywords}

Chiroderma gorgasi, Chiroderma improvisum, cryptic species, cytochrome c oxidase subunit 1, Lesser Antilles 


\section{Introduction}

Cryptic species, phenotypically similar organisms that are classified as a single species but are genetically divergent lineages, are being discovered at a greater rate due to the increasing prevalence of molecular methods, such as DNA barcoding (e.g., Hebert et al. 2004). It has been estimated that Neotropical mammalian biodiversity is underestimated by one-third ( $\operatorname{Lim} 2012)$. At typical lowland tropical forest sites, bats comprise the majority of mammal species diversity (Voss and Emmons 1996), so more species are expected to be recognized in this group as traditional taxonomic hypotheses are tested by genetic techniques. In addition, new surveying methods such as the use of triple-high netting systems to catch higher flying aerial insectivorous bats, and harp traps to target species that may be able to better detect mist nets, is decreasing the sampling bias associated with traditional mist nets set just above ground level.

The big-eyed bats in the genus Chiroderma Peters (Phyllostomidae) are characterized by greatly reduced nasal bones in the skull and a combination of external features including a white dorsal stripe that does not extend onto the head; legs and interfemoral membrane conspicuously hairy; and relatively large eyes (Straney 1984; Gardner 2008). The genus currently comprises six species (Simmons 2005, Taddei and Lim 2010): C. doriae Thomas, 1891 occurs in central-eastern Brazil and Paraguay; C. improvisum Baker \& Genoways, 1976 is endemic to the Lesser Antillean islands of Guadeloupe, Montserrat, and Saint Kitts (Beck et al. 2016); C. salvini Dobson, 1878 is found from Mexico to Bolivia (recent records from Brazil are misidentifications of C. villosum Peters, 1860 - see Brandão et al. 2019); C. trinitatum Goodwin, 1958 is distributed from Honduras (Turcios-Casco et al. 2020) and Costa Rica to Amazonian Brazil and Trinidad; C. villosum ranges from Mexico to southeastern Brazil and Trinidad; and C. vizottoi Taddei \& Lim, 2010 is found only in northeastern Brazil.

The systematics of Chiroderma was last reviewed by Baker et al. (1994) based on a phylogenetic study of the mitochondrial DNA cytochrome $b$ (Cytb) gene; however, each of the five species known at the time was represented by a single specimen. With broader geographic coverage, we re-assess the distributional range, genetic diversity, and morphological differences in the genus.

\section{Material and methods}

\section{Fieldwork}

We conducted a survey of bats on the Caribbean island of Nevis from 24-29 April 2016. Live traps used included a harp trap and $6 \mathrm{~m}$ or $12 \mathrm{~m}$ mist nets set singly in the forest understory or on a triple-high telescoping pole system. Traps were regularly monitored for the first 2-3 hours after sunset when bat activity is the highest after they leave their roosts to feed. Individuals not kept as part of the representa- 
tive collection documenting the species diversity were released at point of capture. A combined scientific research and export permit (F002) was issued through the authority of the Nevis Historical and Conservation Society. An Animal Use Protocol (2016-01) was obtained from the Royal Ontario Museum Animal Care Committee. An import permit (\#2016-02101-4) was authorized by the Canadian Food Inspection Agency. Use of wild mammals followed the guidelines of the American Society of Mammalogists (Sikes et al. 2016).

\section{Molecular analyses}

The cytochrome c oxidase subunit 1 (CO1) gene is the best represented molecular marker for Chiroderma on the genetic sequence database GenBank (www.ncbi.nih.gov/ genbank). There are 117 samples from nine countries in Central and South America (Brazil, Ecuador, El Salvador, French Guiana, Guatemala, Guyana, Mexico, Panama, and Suriname). We add 26 new sequences to bring the sample size to 143 sequences representing 12 countries in the Neotropics, including Venezuela, Peru, and Nevis, and five species in the genus (Appendix 1). There are no tissue samples or nucleotide sequences on GenBank of any genes for the recently described Chiroderma vizottoi (Taddei and Lim 2010). Outgroup taxa were other genera in the subtribe Vampyressina Baker et al., 2016 (Platyrrhinus incarum Thomas, 1912 and Uroderma bilobatum Peters, 1866) of the New World leaf-nosed bats, for direct comparison to Baker et al. (1994) in their analysis of Cytb. Alternative phylogenetic relationships within the subtribe are given by Baker et al. (2016) and Rojas et al. (2016). We also analyzed Cytb, but there are only 11 sequences on GenBank, although we did add one new sequence of Chiroderma trinitatum gorgasi from Panama (Appendix 2).

Molecular methods for new sequences of CO1 follow the protocol for DNA extraction, PCR amplification, and automated nucleotide sequencing outlined in Lim (2017). For Cytb, extraction, amplification, and sequencing followed Lim et al. (2008). Base calls were confirmed with bidirectional sequences and aligned using Sequencher version 4.8 (Gene Code Corporation, Ann Arbor, Michigan). Phylogenetic and molecular evolutionary analyses were conducted using MEGA version 6 (Tamura et al. 2013). For a robust comparison of phylogeny, we used parsimony as a method that minimizes evolutionary change without an explicit model of evolution and maximum likelihood as a probabilistic method with an explicit model of evolution. Maximum parsimony used the subtree pruning regrafting inference method with 500 bootstrap replicates to test branch supports. Maximum likelihood used the Tamura 3-parameter substitution model and gamma distributed rates with invariant sites for COI as determined by the best fit test. For Cytb, the Tamura Nei model and gamma rates were the best fit. Tree inference used nearest neighbor interchange heuristic inference with 500 bootstrap replicates. Genetic distances were calculated with the Tamura 3-parameter model with gamma distributed rates among sites for the larger COI dataset. 


\section{Morphological analyses}

Morphological and morphometric comparisons included 138 specimens from five species of Chiroderma, including two C. improvisum, four C. doriae, seven C. salvini, 58 C. trinitatum, and 66 C. villosum (Appendix 3). We also analyzed the holotypes of $C$. trinitatum gorgasi Handley, 1960 and C. trinitatum trinitatum Goodwin, 1958, but did not have specimens of the most recently described C. vizottoi. Only adults (defined as having closed cranial sutures and complete epiphyseal ossification of metacarpal and phalanx joints) of both sexes were examined. Specimens are deposited in the following institutions; Royal Ontario Museum (ROM, Toronto, Canada); National Museum of Natural History (USNM, Washington, DC, USA); American Museum of Natural History (New York, USA); Texas Tech University (Lubbock, USA); and Field Museum of Natural History (Chicago, USA).

Measurements defined below were taken with digital calipers accurate to $0.01 \mathrm{~mm}$ following the descriptions of Handley (1960): forearm length (FA); greatest length of skull (GSL); interorbital width (IOW); postorbital width (POW); braincase width (BCW); condyloincisive length (CIL); zygomatic breadth (ZB); width across upper molars (M-M); width across upper canines (C-C); and length of maxillary toothrow (C-M). An analysis of variance (ANOVA) for each measurement and a multivariate analysis of variance (MANOVA) were performed to examine the significance of morphometric divergence among species of Chiroderma. The level of significance was $p=0.05$ for all statistical tests. The homoscedasticity of each variable was tested using Bartlett's test with the $\mathrm{R}$ package mvoutliers. Statistical analyzes were performed using R 3.1.0 (R Core Team 2005) and PAST 2.17. Variables were log-transformed and a correlation matrix was used in a Principal Components Analysis (PCA) to assess phenetic differences in multivariate morphological space.

\section{Results}

We report the first occurrence of Chiroderma improvisum (Fig. 1) from Nevis in the northern Leeward Islands of the Lesser Antilles in the Caribbean. An adult male was caught at Barnes Ghaut on April 28, 2016, in a harp trap set across a dry ravine in forest bisected by a road and surrounded by residential homes (Fig. 2). Other equipment deployed included $6 \mathrm{~m}$ mist nets set on a triple-high telescoping pole system, a single $6 \mathrm{~m}$ mist net, and a single $12 \mathrm{~m}$ mist net from 1900-2100 h. In addition to the new distributional record for the island, one Ardops nichollsi, one Noctilio leporinus, and 12 Artibeus jamaicensis were captured.

\section{Molecular analyses}

For COI, the 657 basepairs (bp) at the 5' end were available for most (82\%) of the specimens analyzed. The complete $1140 \mathrm{bp}$ of Cytb were available, including the newly generated sequence, for most (75\%) of the specimens analyzed. The topology of the Chiroderma COI maximum likelihood tree identified six primary terminal clades with (1) C. salvini as 


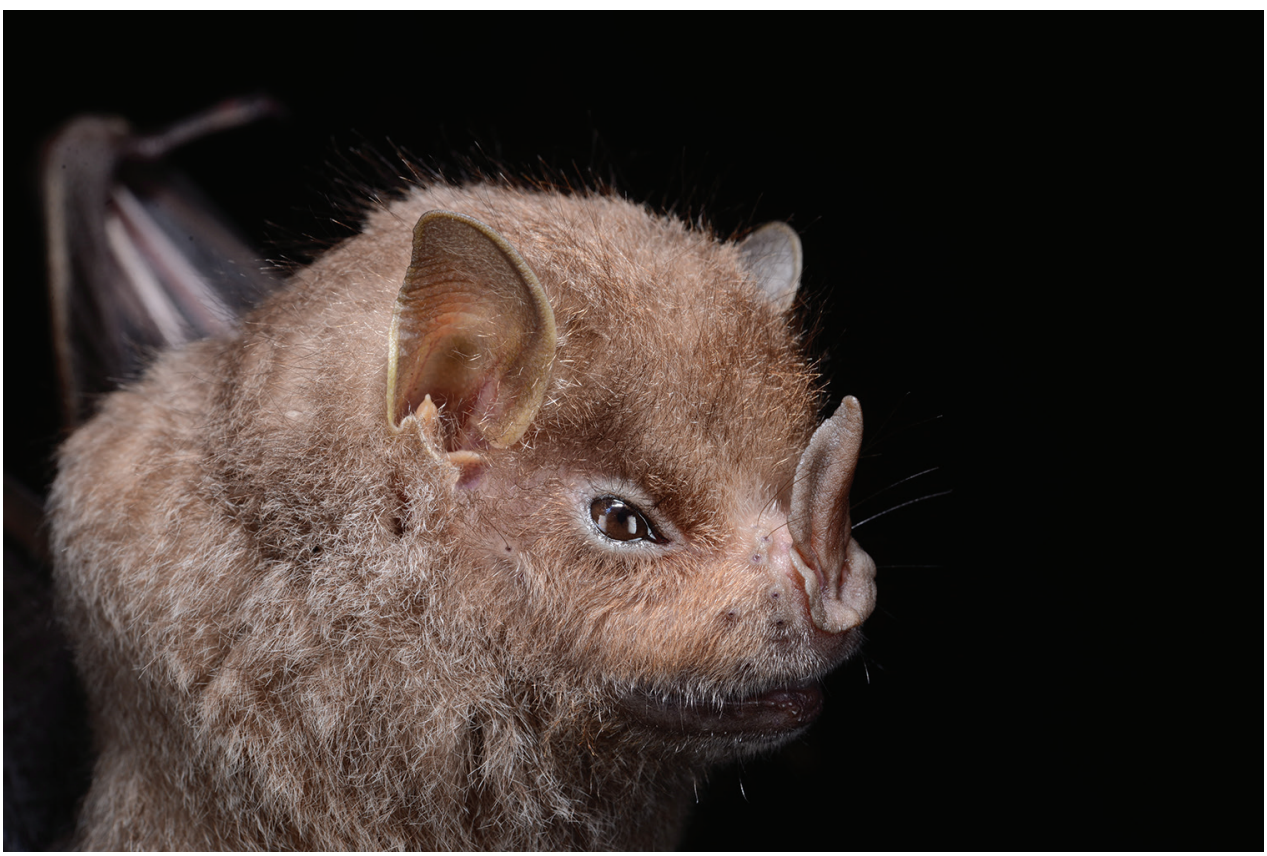

Figure I. First record of the big-eyed bat Chiroderma improvisum from Nevis (ROM 126002).

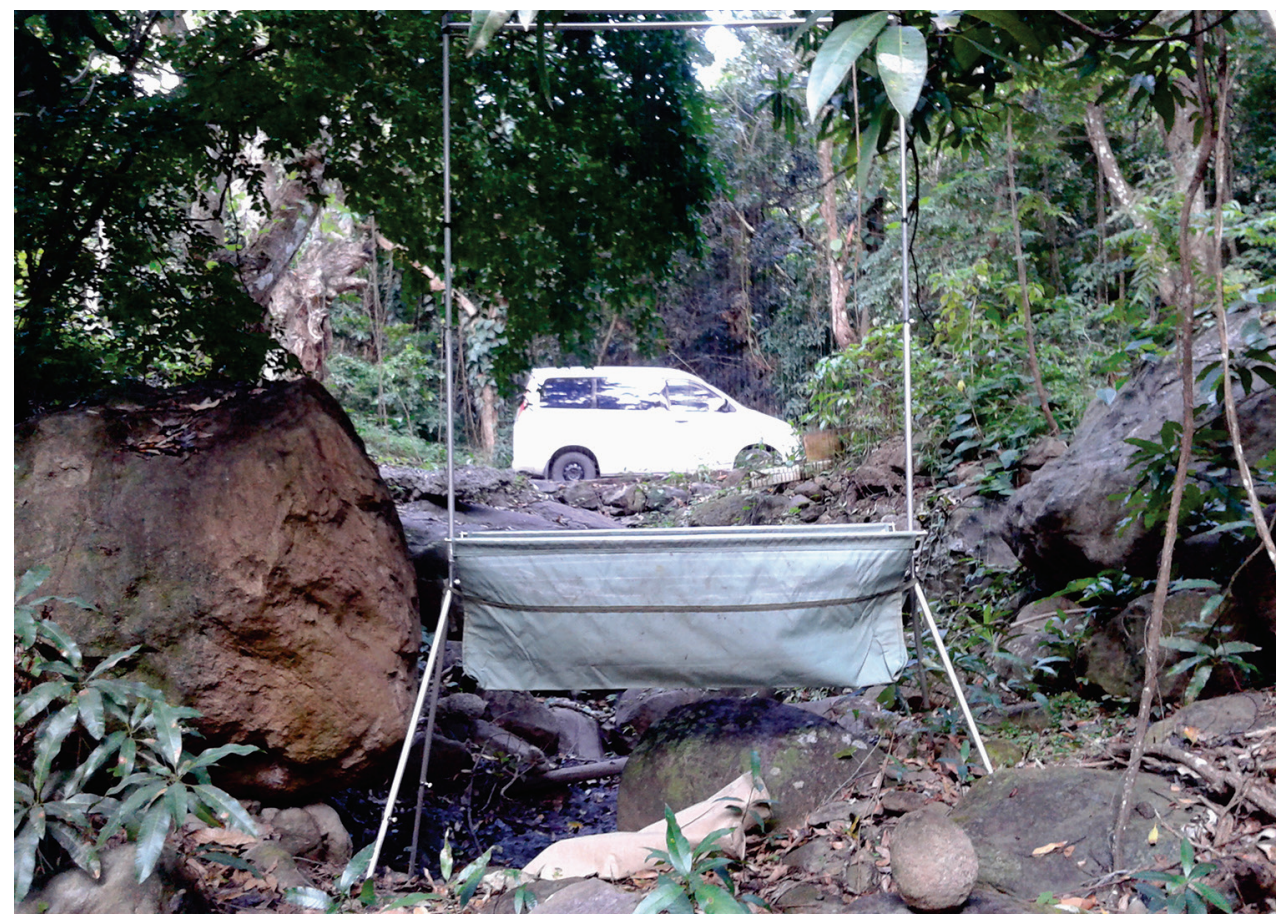

Figure 2. Collecting locality of the first record of the big-eyed bat Chiroderma improvisum from Nevis caught in a harp trap on April 28, 2016. The habitat is a dry ravine within forest that is bisected by a road in the residential area of Barnes Ghaut. 


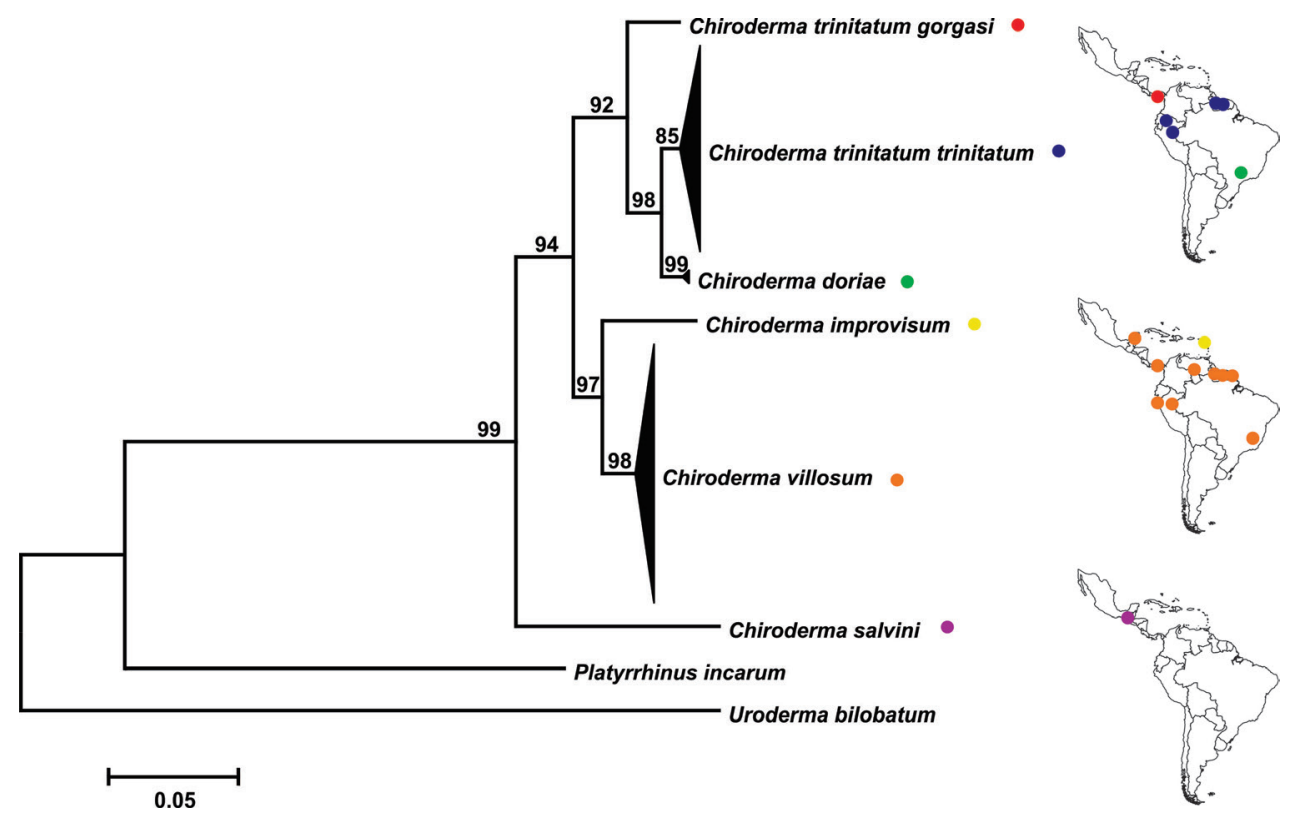

Figure 3. Maximum likelihood tree of cytochrome c oxidase subunit 1 gene for big-eyed bats Chiroderma and general localities of molecular sampling sites. Bootstrap percentages show support at each node.

sister species to all other taxa; (2) C. improvisum and (3) C. villosum as sister species; and (4) C. doriae sister to (5) C. trinitatum trinitatum with (6) C. trinitatum gorgasi sister to these taxa (Fig. 3; Suppl. material 1: Fig. S1). These phylogenetic relationships were supported by bootstrap values $\geq 85$ and were congruent with the maximum parsimony tree (Suppl. material 2: Fig. S2), which had bootstrap values $\geq 73$. Not surprisingly for linked mtDNA loci, the same interspecific topology was recovered by the smaller Cytb dataset analyzed by maximum likelihood (Suppl. material 3: Fig. S3) and maximum parsimony (Suppl. material 4: Fig. S4), except for lower bootstrap supports. The unexpected result was the paraphyly of $C$. trinitatum in relation to $C$. doriae. The sister-group relationship of C. t. trinitatum and $C$. doriae was well supported by values $\geq 73$ in all molecular analyses.

Interspecific genetic distances of the larger COI dataset ranged from $11.3 \%$ between $C$. doriae and C. salvini to $2.5 \%$ between C. doriae and C. t. trinitatum (Table 1). The sequence divergence between C. t. trinitatum and C. t. gorgasi was 3.9\%. Intraspecific distances were $1 \%$ within C. villosum, $0.9 \%$ within C. t. trinitatum, and $0.2 \%$ within $C$. doriae, but three taxa were represented by only one sample.

\section{Morphological analyses}

Cranial and body measurements for the six taxa of Chiroderma identified in the molecular analyses are shown in Table 2. Chiroderma trinitatum gorgasi and C. trinitatum trinitatum are the smallest members of the genus, whereas $C$. improvisum is the largest for most measurements. In the PCA, there are three main groups of species (Fig. 4). The 
Table I. Genetic divergence of cytochrome c oxidase subunit 1 for the big-eyed bat Chiroderma and outgroup taxa Uroderma and Platyrrhinus. Interspecific distances shown in the lower left matrix; intraspecific distances shown in bold in the diagonal.

\begin{tabular}{lcccccccc}
\hline & $(\mathbf{1})$ & $(\mathbf{2})$ & $\mathbf{( 3 )}$ & $\mathbf{( 4 )}$ & $\mathbf{( 5 )}$ & $\mathbf{( 6 )}$ & (7) & (8) \\
\hline U. bilobatum (1) & - & & & & & & & \\
P. incarum (2) & 0.203 & - & & & & & & \\
C. villosum (3) & 0.223 & 0.178 & $\mathbf{0 . 0 1 0}$ & & & & & \\
C. improvisum (4) & 0.231 & 0.194 & 0.047 & - & & & & \\
C. t. trinitatum (5) & 0.222 & 0.184 & 0.067 & 0.075 & $\mathbf{0 . 0 0 9}$ & & & \\
C. salvini (6) & 0.205 & 0.185 & 0.093 & 0.101 & 0.110 & - & & \\
C. t. gorgasi (7) & 0.195 & 0.149 & 0.059 & 0.070 & 0.039 & 0.101 & - & \\
C. doriae (8) & 0.213 & 0.173 & 0.066 & 0.077 & 0.025 & 0.113 & 0.039 & $\mathbf{0 . 0 0 2}$ \\
\hline
\end{tabular}

Table 2. Cranial and body measurements of six taxa of the big-eyed bat Chiroderma. See Material and methods for variable abbreviations.

\begin{tabular}{|c|c|c|c|c|c|c|}
\hline & $\begin{array}{c}\text { C. trinitatum } \\
\text { gorgasi }(N=11)\end{array}$ & $\begin{array}{c}\text { C. trinitatum } \\
\text { trinitatum }(N=47)\end{array}$ & $\begin{array}{l}\text { C. villosum } \\
(N=66)\end{array}$ & $\begin{array}{c}\text { C. salvini }(N \\
=6)\end{array}$ & C. doriae $(N=4)$ & $\begin{array}{l}\text { C. improvisum } \\
(N=2)\end{array}$ \\
\hline FA & $37.7(37.0-40.5)$ & $38.9(37.1-42.6)$ & $47.9(44.6-51.0)$ & $49.6(49.3-50.0)$ & $54(53.0-55.0)$ & $58.2(56.2-60)$ \\
\hline GLS & $21.2(20.6-21.7)$ & $21.1(20.0-22.7)$ & $24.5(23.2-25.7)$ & $26.1(24.2-26.5)$ & $28.2(27.6-28.9)$ & $29.3(28.7-29.9)$ \\
\hline CLI & $17.3(16.3-18.1)$ & $17.4(16.1-18.8)$ & $20.3(18.7-21.58)$ & $21.6(21.5-22.3)$ & $23.9(23.1-24.5)$ & $26.3(25.3-27.8)$ \\
\hline ZB & $13.0(12.5-13.5)$ & $12.9(11.7-14.2)$ & $15.5(14.4-16.7)$ & $16.2(15.8-16.7)$ & $17.84(17.7-18.1)$ & $18.75(18.5-19)$ \\
\hline POW & $5.3(4.9-5.6)$ & $5.3(5.8-5.8)$ & $5.9(5.3-6.3)$ & $6.2(5.9-6.3)$ & $6.4(6.1-6.6)$ & 6.6 \\
\hline IOW & $5.6(5.2-5.9)$ & $5.5(5.0-6.2)$ & $6.0(5.5-6.8)$ & $6.8(6.1-7.3)$ & $7.1-7.8)$ & $7.4(7.4-7.4)$ \\
\hline $\mathrm{BCW}$ & $9.4(8.9-9.8)$ & $9.6(9.2-10.4)$ & $10.7(10.1-11.5)$ & $11.21(11.0-11.5)$ & $11.9(11.3-12.1)$ & $12.0(11.5-12.5)$ \\
\hline C-M & $7.0(6.5-7.3)$ & $7.1(6.7-7.8)$ & $8.7(8.1-9.4)$ & $9.4(9.1-9.4)$ & $10.3(10.0-11.1)$ & $11.0(10.9-11.1)$ \\
\hline M-M & $9.6(9.2-10.0)$ & $9.5(8.7-10.3)$ & $11.3(10.3-12.4)$ & $12.0(11.5-12.3)$ & $13.3(13.0-13.7)$ & $13.8(13.6-13.9)$ \\
\hline C-C & $4.7(4.4-5.0)$ & $4.6(4.1-5.0)$ & $5.8(5.3-6.3)$ & $6.1(6.0-6.2)$ & $6.5(6.3-6.8)$ & $7.4(7.4-7.4)$ \\
\hline
\end{tabular}

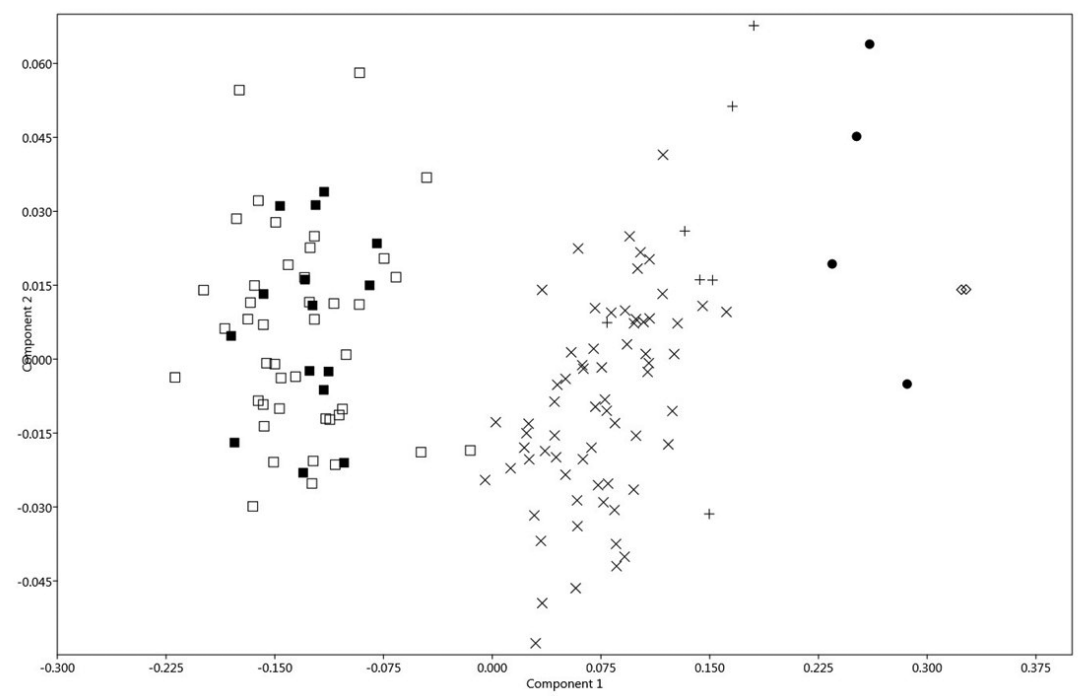

Figure 4. Principal Component Analysis (PCA) carried out using the correlation matrix of ten measurements for six taxa of the big-eyed bat Chiroderma. C. trinitatum gorgasi $(\square)$ C. trinitatum trinitatum $(\square)$, C. salvini (×), C. villosum (+), C. doriae $(\bullet)$, and C. improvisum $(\diamond)$. 
Table 3. Eigenvalue and loadings for the first and second components in the Principal Component Analysis (PCA) of big-eyed bats Chiroderma. See Material and methods for variable abbreviations.

\begin{tabular}{llc}
\hline & PC1 & PC2 \\
\hline Eigenvalue & 1.57 & 0.53 \\
\% Variance & 91.4 & 3.11 \\
IOW & 0.25 & 0.44 \\
POW & 0.21 & 0.40 \\
C-M & 0.34 & -0.23 \\
GSL & 0.31 & -0.05 \\
BCW & 0.34 & 0.35 \\
CIL & 0.34 & 0.07 \\
C-C & 0.36 & -0.23 \\
M-M & 0.36 & -0.14 \\
ZB & 0.37 & -0.12 \\
FA & 0.42 & 0.32 \\
\hline
\end{tabular}

first group is formed by the smaller taxa C. t. gorgasi and C. t. trinitatum. The second group has species with medium size, C. villosum and C. salvini, and the third group is formed by the largest species of the genus, $C$. doriae and $C$. improvisum. The first and second principal components (PC1 and $\mathrm{PC} 2$ ) explained $94.5 \%$ of the total variation. $\mathrm{PC} 1$ shows a pattern in general size variation and is explained mostly by C-M, C-C, and FA. PC2 has positive loadings for most measurements, especially IOW, with the exception of C-M, C-C, M-M, and ZB that have negative loadings (Table 3). All the species seem to occupy the entire range of $\mathrm{PC} 2$, indicating that the contrast among measurements is negligible and it is not responsible for the separation of groups.

All variables had $p>0.05$ for Bartlett's test of homoscedasticity, indicating constant variances ( $p$ values: $\mathrm{FA}=0.06, \mathrm{GSL}=0.25, \mathrm{IOW}=0.59, \mathrm{POW}=0.31, \mathrm{BCW}=0.06, \mathrm{CIL}$ $=0.45, \mathrm{ZB}=0.08, \mathrm{M}-\mathrm{M}=0.32, \mathrm{C}-\mathrm{C}=0.08$, and $\mathrm{C}-\mathrm{M}=0.06)$. The MANOVA and the ANOVA demonstrated that C. t. trinitatum and C. t. gorgasi are significantly different from the other taxa of Chiroderma $(\mathrm{P}<0.001)$ for all measured variables (Appendix 3). By contrast, $C$. t. gorgasi and C. t. trinitatum are not significantly different from each other $(p=0.16, F=56.0)$. However, the ANOVA showed that one measurement, $\mathrm{BCW}(p=$ $0.01 ; F=62.0$ ), was significantly larger for $C$. t. trinitatum than for $C$. t. gorgasi. All other cranial measurements had smaller mean values for $C$. t. trinitatum than for $C$. t. gorgasi.

Although similar in size, C. t. trinitatum has a more robust breadth of the braincase than C. t. gorgasi. Chiroderma t. trinitatum also has an accessory cusp on the second lower premolar, which is absent in C. t. gorgasi (Fig. 5). In the genetic analyses, C. t. trinitatum is well supported as the sister species to $C$. doriae and does not share a most recent common ancestor with C. t. gorgasi. We consider this as a previous example of a cryptic species and therefore now recognize $C$. gorgasi as a distinct species from $C$. trinitatum. Sáez and Lozano (2005: 111) considered cryptic species to be "groups of organisms that are morphologically indistinguishable from each other, yet found to belong to different evolutionary lineages". They also stated that "after detailed comparisons of morphological and non-morphological features, we can often establish key 


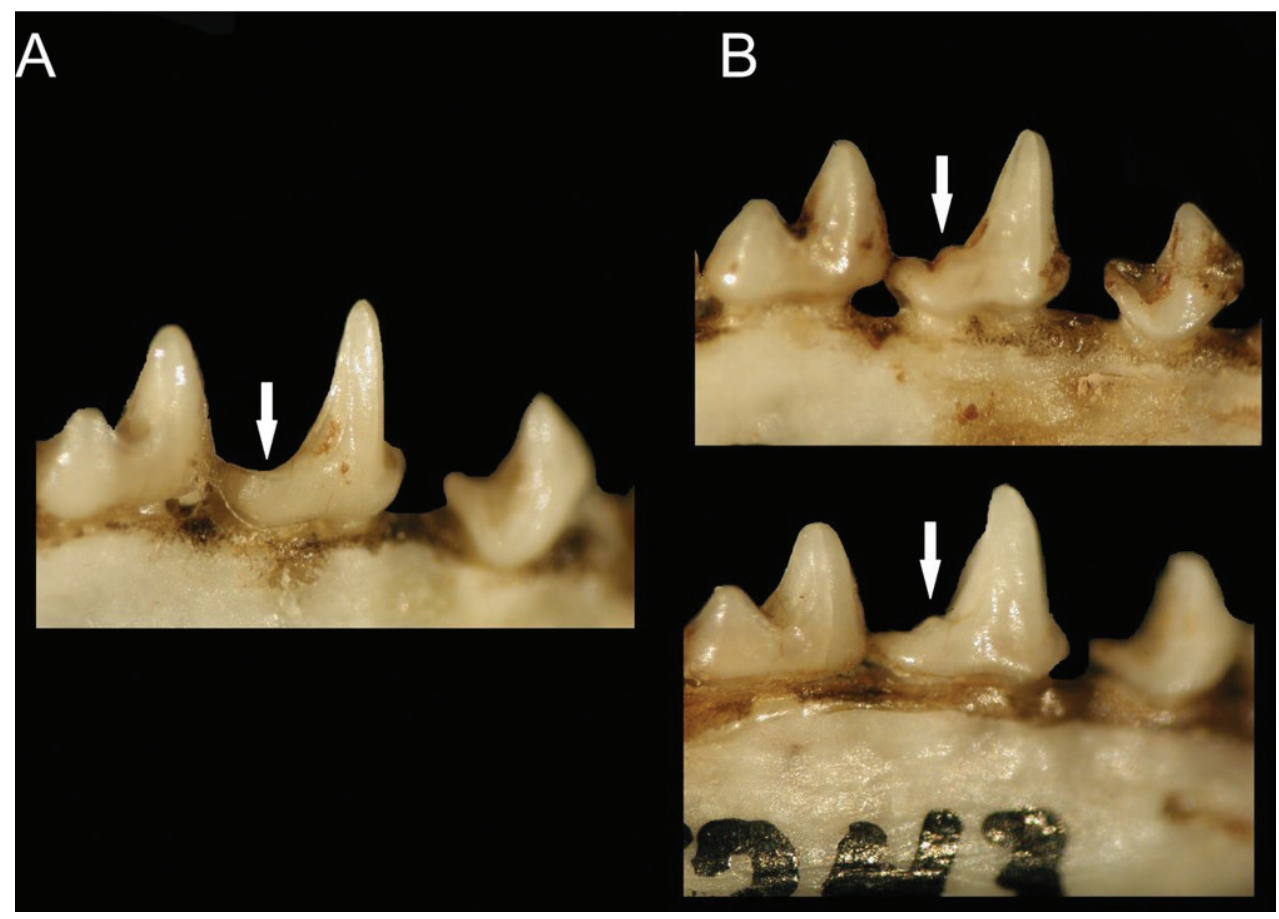

Figure 5. Lateral view of the second lower premolar on the right mandible of $\mathbf{A}$ Chiroderma gorgasi and $\mathbf{B}$ C. trinitatum. The arrow points to the accessory cusp that is absent in $C$. gorgasi and present in $C$. trinitatum. But note the variation in cusp formation in C. trinitatum.

morphological characters for their identification. In those cases, we can then refer to pseudo-cryptic or pseudo-sibling species”. Because Handley's original description was qualitative and univariate, we offer an amended description of this taxon.

\section{Taxonomic account}

\section{Chiroderma gorgasi Handley, 1960}

Chiroderma gorgasi Handley, 1960:464

Chiroderma trinitatum gorgasi Barriga-Bonilla, 1965:246

Material examined. Holotype. - USNM 309903 (Field number COH 5436), adult male with skin, skull and partial skeleton. Collected on March 6, 1959, by C. O. Handley, Jr, and B. R. Feinstein in Tacarcuna Village ( $\left.8^{\circ} 05^{\prime} \mathrm{N}, 77^{\circ} 17^{\prime} \mathrm{W}\right), 3200$ feet [975 meters], Río Pucro, Darién, Panama.

Geographic distribution. Chiroderma gorgasi is distributed west of the Andes in northwestern Ecuador (Albuja 1989), western Colombia (Gardner 2008), Panama 


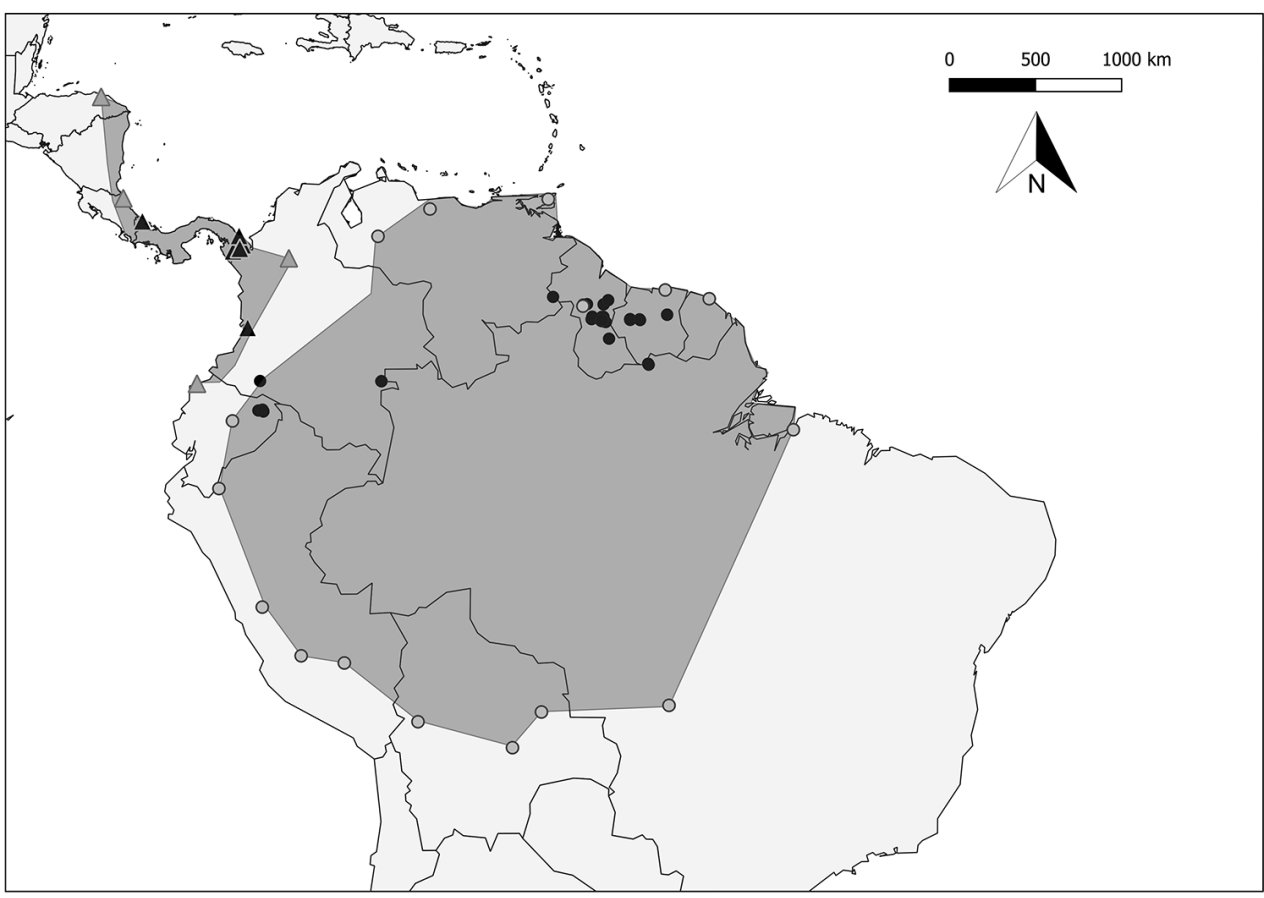

Figure 6. Geographic distribution of Chiroderma gorgasi $(\mathbf{\Delta})$ and C. trinitatum $(\bullet)$ localities analyzed in our study (See Appendix 3) (O) Represents marginal localities reported for C. trinitatum and $(\triangle) C$. gorgasi reported by previous papers (Handley 1967; Pine et al. 1970; Ojasti and Linares 1971; Gardner 1976; Albuja 1989; Timm and LaVal 1998; Lim and Engstrom 2001; Genoways et al. 1981; Webster and Fugler 1984; Anderson 1997; Ochoa et al. 1988; Simmons and Voss 1998; Gardner 2008).

(Handley 1960), Costa Rica (LaVal and Rodríguez-Herrera 2002), and Honduras (Turcios-Casco et al. 2020) (Fig. 6).

Description. Chiroderma gorgasi is a small species of Chiroderma (FA 37.0-40.5; GLS 20.2-22.5) that is similar in size to C. trinitatum (sensu stricto) (Table 2). Overall, the dorsal pelage is tricolor varying from light to dark brown (Fig. 7). The dorsal hairs have a dark brown band at the base, a buff coloration in the middle, and brown tips. A white medial stripe extends from the interscapular region to the base of the rump. Proximal two-thirds of forearm hairy. Basal third of uropatagium hairy. Conspicuous white facial stripes extend from the noseleaf to the inner base of the ears, and from the posterior part of the upper lip to the base of the ears. The uropatagium is medium brown. The skull has an elongated braincase with an undeveloped sagittal and lambdoidal crest. The nasal aperture is short, not extending beyond the second premolar. The occipital is rounded in posterior view. The upper incisors are thin and elongated with parallel or convergent tips, which may or may not touch apically. The second lower premolar lacks a third cusp (Fig 5). The postorbital processes are undeveloped and rounded (Fig. 8).

Comparisons. Chiroderma gorgasi is morphologically very similar to $C$. trinitatum. Both species have a small cranial and body size for the genus (Table 2, Fig. 4), an 


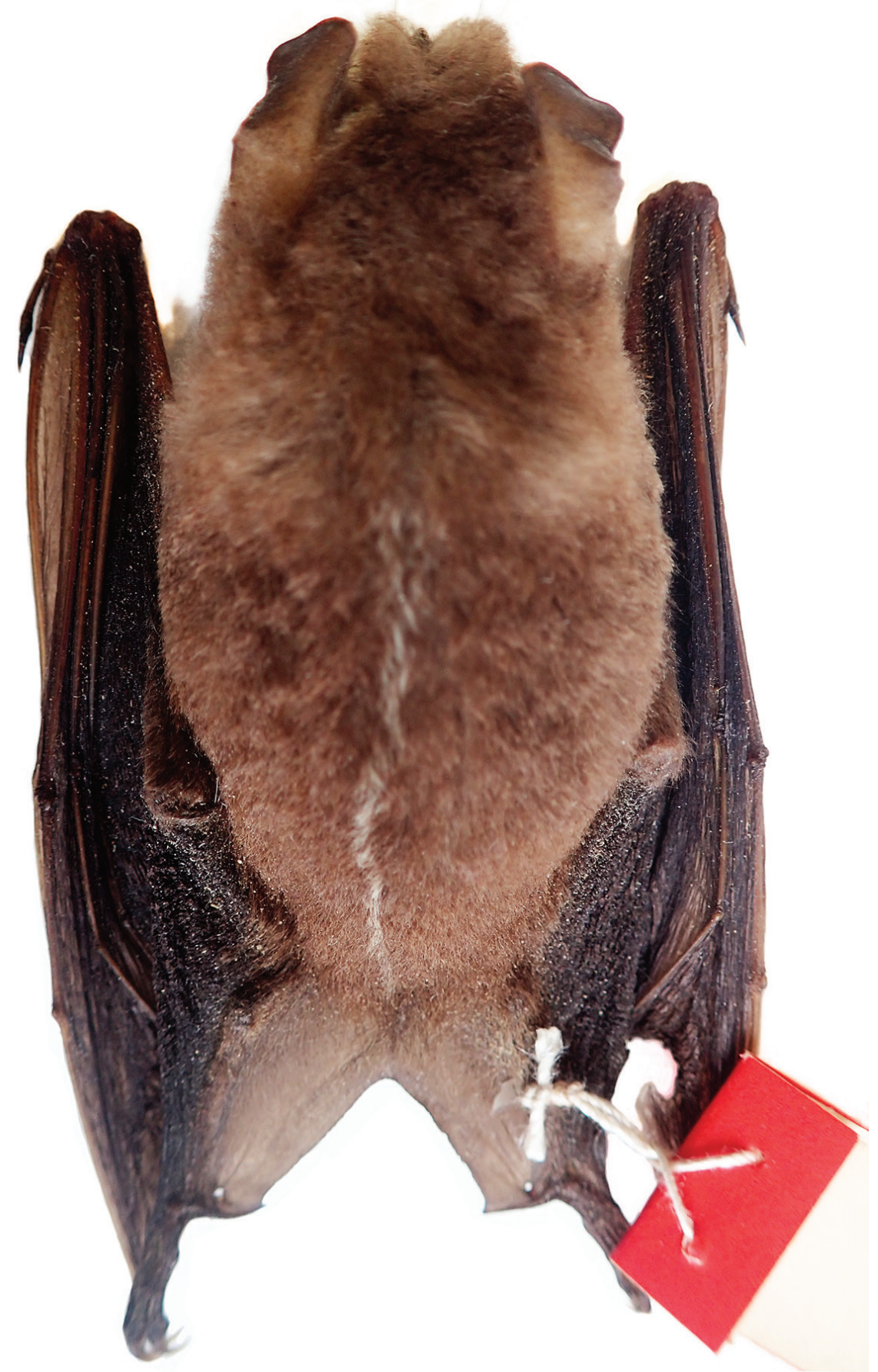

Figure 7. Dorsal view of the skin of the holotype of Chiroderma gorgasi (USNM 309903). 


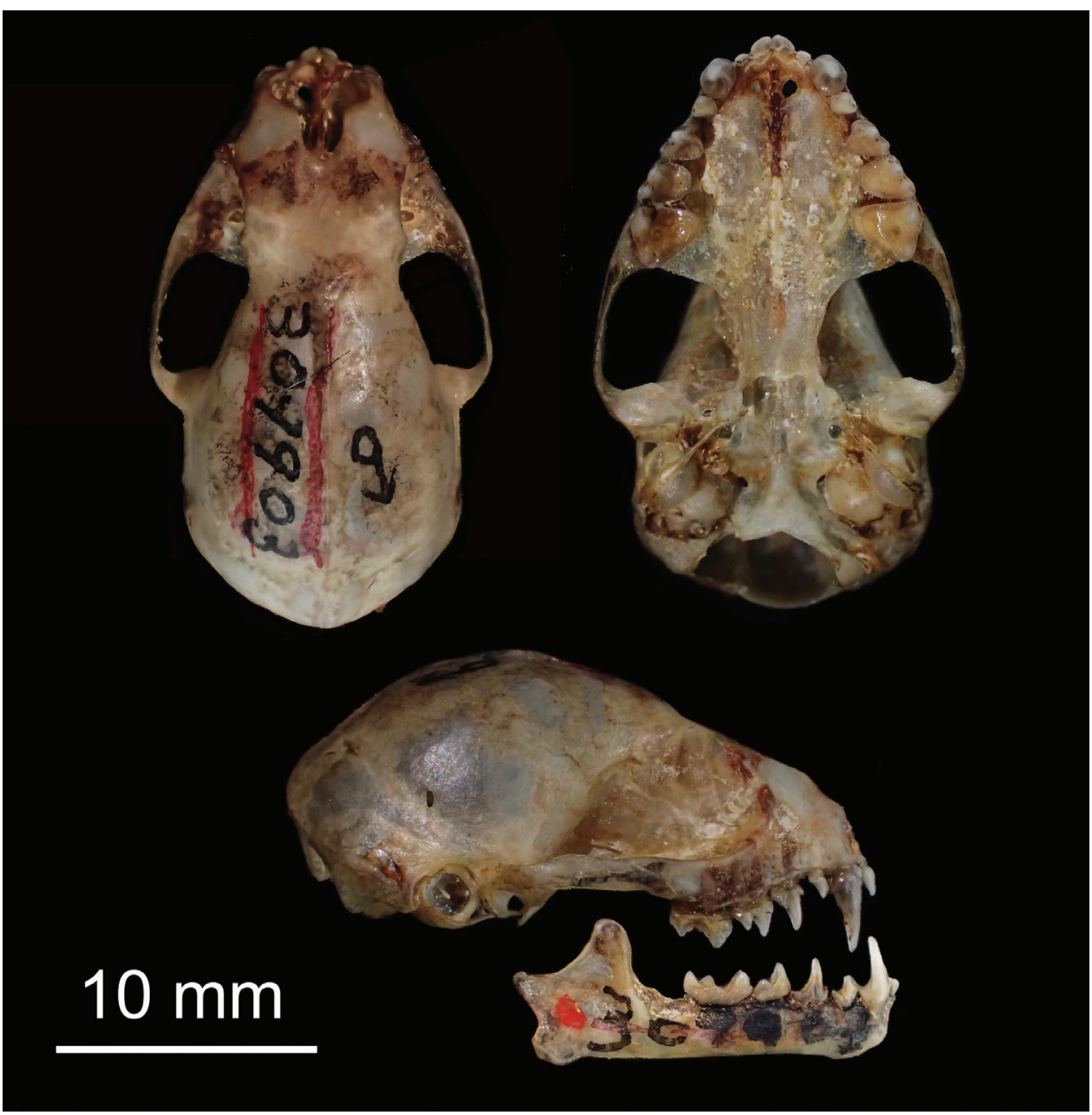

Figure 8. Dorsal, ventral, and lateral views of the skull of the holotype of Chiroderma gorgasi (USNM 309903).

undeveloped sagittal and lambdoidal crest, a rounded occipital complex, a short nasal aperture, and undeveloped supraorbital region. However, C. trinitatum has a third posterior cusp on the second lower premolar, which is absent in C. gorgasi (Fig. 5). This cusp in $C$. trinitatum may vary from very pointed and developed to rounded and less marked, but is always present. In addition, $C$. gorgasi tends to have a broader braincase (Table 4) and a flatter supraorbital region, which tends to be deeper in C. trinitatum.

Chiroderma gorgasi is easily distinguished from other species of the genus by its smaller cranial and body size (Table 2). C. villosum shares with $C$. gorgasi an elongated braincase, rounded occipital region in dorsal view, and absence of a third cusp on the second lower premolar. However, $C$. gorgasi has an undeveloped postorbital processes, a short nasal aperture, and conspicuous white stripes on the face and back, whereas C. villosum has a very developed and pointed postorbital processes, a long nasal ap- 
Table 4. ANOVA comparing Chiroderma trinitatum trinitatum to C. doriae, C. improvisum, C. villosum, C. salvini, and C. trinitatum gorgasi. * indicates significantly distinct variables ( $p \leq 5 \%)$.

\begin{tabular}{lccccc}
\hline Variables & C. doriae & C. improvisum & C. villosum & C. salvini & C. t. gorgasi \\
\hline GSL & $<2.2 \mathrm{e}-16^{*}$ & $<2.2 \mathrm{e}-16^{*}$ & $<2.2 \mathrm{e}-16^{*}$ & $<2.2 \mathrm{e}-16^{*}$ & 0.1541 \\
CI & $<2.2 \mathrm{e}-16^{*}$ & $<2.2 \mathrm{e}-16^{*}$ & $<2.2 \mathrm{e}-16^{*}$ & $<2.2 \mathrm{e}-16^{*}$ & 0.4423 \\
ZB & $<2.2 \mathrm{e}-16^{*}$ & $<2.2 \mathrm{e}-16^{*}$ & $<2.2 \mathrm{e}-16^{*}$ & $<2.2 \mathrm{e}-16^{*}$ & 0.3094 \\
POW & $<2.2 \mathrm{e}-16^{*}$ & $1.373 \mathrm{e}-06^{*}$ & $<2.2 \mathrm{e}-16^{*}$ & $1.061 \mathrm{e}-12^{*}$ & 0.6747 \\
IOW & $<2.2 \mathrm{e}-16^{*}$ & $1.347 \mathrm{e}-09^{*}$ & $2.366 \mathrm{e}-14^{*}$ & $1.355 \mathrm{e}-14^{*}$ & 0.6272 \\
BWC & $<2.2 \mathrm{e}-16^{*}$ & $2.602 \mathrm{e}-08^{*}$ & $<2.2 \mathrm{e}-16^{*}$ & $<2.2 \mathrm{e}-16^{*}$ & $0.0339^{*}$ \\
M-C & $<2.2 \mathrm{e}-16^{*}$ & $<2.2 \mathrm{e}-16^{*}$ & $<2.2 \mathrm{e}-16^{*}$ & $<2.2 \mathrm{e}-16^{*}$ & 0.5257 \\
B-M & $<2.2 \mathrm{e}-16^{*}$ & $1.527 \mathrm{e}-15^{*}$ & $<2.2 \mathrm{e}-16^{*}$ & $<2.2 \mathrm{e}-16^{*}$ & 0.1444 \\
B-C & $<2.2 \mathrm{e}-16^{*}$ & $<2.2 \mathrm{e}-16^{*}$ & $<2.2 \mathrm{e}-16^{*}$ & $<2.2 \mathrm{e}-16^{*}$ & 0.1251 \\
FA & $<2.2 \mathrm{e}-16^{*}$ & $<2.2 \mathrm{e}-16^{*}$ & $<2.2 \mathrm{e}-16^{*}$ & $<2.2 \mathrm{e}-16^{*}$ & 0.1753 \\
\hline
\end{tabular}

erture, which extends beyond the first molar, a conspicuous posterior palatine spine, and usually incipient white stripes on the face and back. Chiroderma salvini resembles C. gorgasi in the undeveloped sagittal and lambdoidal crest and by the rounded postorbital processes, but a set of other cranial characters distinguish both species, such as a triangular occipital complex and a long nasal aperture. In the dentition, $C$. gorgasi can be readily distinguished from $C$. salvini and C. villosum by having a tall first lower premolar, with a crown height approximately $2 / 3$ the height of the crown of the second lower premolar, and placed approximately in the middle of the distance between the canine and the second lower premolar. In C. salvini and C. villosum, this tooth is much smaller, usually with a low crown, shorter than the mesiodistal length of the tooth, and is nearer to the canine than to the second lower premolar.

Chiroderma doriae and C. improvisum are the largest species of the genus, and unlike C. gorgasi have a triangular occipital complex in dorsal view, a pointed and developed supraorbital region, a relatively more developed sagittal and lambdoidal crest, and a long nasal aperture. In addition, $C$. doriae also tends to have a relatively broader braincase than C. gorgasi and the presence of an undeveloped third cusp in the second lower premolar. We were not able to examine specimens of the more recently described C. vizottoi, but it is larger than C. gorgasi and most similar to $C$. doriae in qualitative craniodental traits.

\section{Discussion}

The only big-eyed bat species occurring in the Caribbean is Chiroderma improvisum, which until recently was known from Guadeloupe (Baker and Genoways 1976) and Montserrat (Jones and Baker 1979; Pierson et al. 1986) by six individuals (Larsen et al. 2007). Subsequently, it was caught on Saint Kitts by Beck et al. (2016) and we are the first to report its occurrence on Nevis. Although this species has been sporadically documented since its discovery, the distribution has broadened in the northern Lesser Antilles but this may be ephemeral depending on weather systems such as hurricanes (Larsen et al. 2007). 
Chiroderma gorgasi was originally described by Handley (1960) using five specimens from the type locality in Panama. The author distinguished the new species from C. trinitatum by its smaller size, deeper brain case, shorter rostrum, shaper lacrimal ridge, bulging forehead, larger upper incisors, and thicker white band in the dorsal hairs. But at that time, $C$. trinitatum was only known by the holotype from Trinidad (Goodwin 1958) so the extent of variation within each species was poorly understood. Based on a specimen from Mitu in Amazonian Colombia, Barriga-Bonilla (1965) recognized the taxon as two subspecies and assigned his Colombian specimen to C. t. gorgasi. The subspecies were considered to be distributed from eastern Panama to western Venezuela for C. t. gorgasi and Trinidad to the Amazon basin for C. t. trinitatum (Jones and Carter 1976). However, with more geographic sampling the initial distinctions between the two taxa were less obvious due to individual and geographic variation (Simmons and Voss 1998), as also demonstrated by our morphometric analysis. But the taxonomy and distributional limits were still contentious with Gardner (2008) recognizing the Andes as the delineation of the subspecies and reassigning the specimen of Barriga-Bonilla (1965) from Mitu, Colombia, to C. t. trinitatum.

Our morphological review identified the presence of three cusps on the second lower premolar in cis-Andean populations referable to $C$. trinitatum and two cusps in trans-Andean populations referable to $C$. gorgasi that also match the taxonomic boundaries of Gardner (2008). Morphometrically, C. trinitatum averages smaller than C. gorgasi in all cranial measurements except for a proportionately broader braincase. Furthermore, our genetic analyses recovered $C$. trinitatum as the well-supported sister species to the larger and morphologically distinctive $C$. doriae, and not to the superficially similar C. gorgasi. Based on this morphological and molecular evidence, we recognize $C$. gorgasi as a distinct species and divergent lineage that does not share the most recent common ancestor with $C$. trinitatum (sensu stricto).

The overall topology of the Cytb tree proposed by Baker et al. (1994) is identical to our tree except for the recognition of $C$. gorgasi, which they did not have a sample of, as the sister species to $C$. trinitatum and $C$. doriae. The evolution of Chiroderma was suggested as occurring primarily by allopatric speciation (Baker et al. 1994). More specifically, C. improvisum arose by peripatric speciation in the Lesser Antilles after dispersing from its most recent common ancestor with C. villosum in South America. The Andes is an obvious geographic barrier separating C. gorgasi from the most recent common ancestor of $C$. trinitatum and $C$. doriae. A dated phylogeny is needed to test whether this is an older sundering event associated with the uplift of the northern Andes in the Late Miocene or a more recent dispersal event followed by isolation and the cessation of gene flow. Rojas et al. (2016) date the divergence of Chiroderma species to the Pliocene-Holocene, but C. gorgasi was not included in their dataset. The allopatric distribution of $C$. trinitatum and $C$. doriae suggests that perhaps the Cerrado Savanna in Brazil acted as a barrier after colonization of the Atlantic Forest from the Amazon, but the records of $C$. doriae for the Cerrado and the discovery of a species of Chiroderma in the dry deciduous forests of the Brazilian Caatinga, C. vizottoi, indicates that species of the genus can adapt to more harsh habitats. The speciation event that gave rise to $C$. salvini and the most recent common ancestor 
of the other species of Chiroderma is speculative without a thorough biogeographic analysis with a dated phylogeny.

Although not an overly species-rich genus, biodiversity surveys and molecular analyses are finding new distributional and taxonomic discoveries in Chiroderma. However, there are still large geographic gaps in sampling throughout the Neotropics, such as the Amazon basin in Brazil and northern South America in Colombia and Venezuela. In addition, this has hindered detailed study of the biogeography of the genus and more broadly the evolution of bats in the Neotropics.

\section{Acknowledgments}

GSTG is grateful to Valéria da Cunha Tavares for the valuable assistance during his $\mathrm{PhD}$ research. GSTG was funded by the Coordenação de Aperfeiçoamento de Pessoal de Nível Superior, Brazil (CAPES; Code 001). Funding for fieldwork in Nevis was obtained by BKL through a generous contribution from the Collections and Research Fieldwork Fund of the Royal Ontario Museum. DNA sequencing was done by Kristen Choffe in the Laboratory of Molecular Systematics at the ROM.

\section{References}

Albuja VL (1989) Adiciones a la fauna de quiropteros del noroccidente del Ecuador. Politécnica 14: $105-111$.

Anderson S (1997) Mammals of Bolivia, taxonomy and distribution. Bulletin of the American Museum of Natural History 231: 1-652.

Baker RJ, Genoways HH (1976) A new species of Chiroderma from Guadeloupe, West Indies (Chiroptera: Phyllostomatidae). Occasional Papers, The Museum, Texas Tech University 39: 1-9. https://doi.org/10.5962/bhl.title.142933

Baker RJ, Solari S, Cirranello A, Simmons NB (2016) Higher level classification of phyllostomid bats with a summary of DNA synapomorphies. Acta Chiropterologica 18: 1-38. https://doi.org/10.3161/15081109ACC2016.18.1.001

Baker RJ, Taddei VA, Hudgeons JL, Van Den Bussche RA (1994) Systematic relationships within Chiroderma (Chiroptera: Phyllostomidae) based on cytochrome $b$ sequence variation. Journal of Mammalogy 75: 321-327. https://doi.org/10.2307/1382550

Barriga-Bonilla E (1965) Estudios mastozoológicos Colombianos, I Chiroptera. Caldasia 9: 241-268.

Beck JD, Loftis AD, Daly JL, Reeves WK, Orlova MV (2016) First record of Chiroderma improvisum Baker \& Genoways, 1976 (Chiroptera: Phyllostomidae) from Saint Kitts, Lesser Antilles. Check List 12: 1-4. https://doi.org/10.15560/12.2.1854

Brandão MV, Garbino GST, Semedo TBF, Feijó A, Nascimento FO, Fernandes-Ferreira H, Rossi RV, Dalponte J, Carmignotto AP (2019) Mammals of Mato Grosso, Brazil: annotated species list and historical review. Mastozoologia Neotropical 26: 263-307. https:// doi.org/10.31687/saremMN.19.26.2.0.03 
Gardner AL (1976) The distributional status of some Peruvian mammals. Occasional Papers Museum of Zoology, Louisiana State University 48: 1-18.

Gardner AL (2008) Genus Chiroderma W. Peters, 1860. In: Gardner AL (Ed.) Mammals of South America. Vol. 1. Marsupials, xenarthrans, shrews, and bats. University of Chicago Press, Chicago, 329-342. https://doi.org/10.7208/chicago/9780226282428.001.0001

Genoways HH, Williams SL, Groen JA (1981) Results of the Alcoa Foundation-Suriname Expeditions. V. Noteworthy records of Surinamese mammals. Annals of the Carnegie Museum 50: 319-32.

Goodwin GG (1958) Three new bats from Trinidad. American Museum Novitates 1877: 1-6. Handley Jr CO (1960) Description of new bats from Panama. Proceedings of the United States National Museum 112: 459-461. https://doi.org/10.5479/si.00963801.112-3442.459

Handley Jr CO (1967) Bats of the canopy of an Amazonian forest. Atas do simposio sobre a biota. Amazonica 5: 211-15.

Hebert PDN, Penton EH, Burns JM, Janzen DH, Hallwachs W (2004) Ten species in one: DNA barcoding reveals cryptic species in the neotropical skipper butterfly Astraptes fulgerator. Proceedings of the National Academy of Sciences of the United States of America 101: 14812-14817. https://doi.org/10.1073/pnas.0406166101

Jones Jr JK, Baker RJ (1979) Notes on a collection of bats from Montserrat, Lesser Antilles. Occasional papers - The Museum, Texas Tech University 60: 1-6. https://doi.org/10.5962/ bhl.title.142952

Jones Jr JK, Carter DC (1976) Annotated checklist, with keys to subfamilies and genera. In: Baker RJ, Jones Jr JK, Carter DC (Eds) Biology of bats of the New World family Phyllostomidae, Part 1. Special Publications, The Museum, Texas Tech University, 7-38.

Larsen RJ, Boegler CA, Genoways HH, Masefield WP, Kirsch RA, Pedersen SC (2007) Mist netting bias, species accumulation curves, and the rediscovery of two bats on Montserrat (Lesser Antilles). Acta Chiropterologica 9: 423-435. https://doi.org/10.3161/17335329(2007)9[423:MNBSAC]2.0.CO;2

LaVal, RK, Rodríguez-Herrera B (2002) Murciélagos de Costa Rica. Instituto Nacional de Biodiversidad, Costa Rica.

Lim BK (2012) Preliminary assessment of neotropical mammal DNA barcodes: an underestimation of biodiversity. The Open Zoology Journal 5 (Suppl 1-M3): 10-17. https://doi. org/10.2174/1874336601205010010

Lim BK (2017) Review of genetic diversification of bats in the Caribbean and biogeographic relationships to Neotropical species based on DNA barcodes. Genome 60: 65-73. https:// doi.org/10.1139/gen-2015-0204

Lim BK, Engstrom MD (2001) Species diversity of bats (Mammalia: Chiroptera) in Iwokrama Forest, Guyana, and the Guianan subregion: Implications for conservation. Biodiversity and Conservation 10: 613-57. https://doi.org/10.1023/A:1016660123189

Lim BK, Engstrom MD, Bickham JW, Patton JC (2008) Molecular phylogeny of New World sheath-tailed bats (Emballonuridae: Diclidurini) based on loci from the four genetic transmission systems in mammals. Biological Journal of the Linnean Society 93: 189-209. https://doi.org/10.1111/j.1095-8312.2007.00942.x 
Ochoa G, Castellanos JH, Ibanez C (1988) Records of bats and rodents from Venezuela. Mammalia 52:175-80. https://doi.org/10.1515/mamm.1988.52.2.175

Ojasti J, Linares OJ (1971) Adiciones a la fauna de murciélagos de Venezuela con notas sobre las especies del genero Diclidurus (Chiroptera). Acta Biologica Venezuelica 7: 421-41.

Pierson ED, Rainey WE, Warner RM, White-Warner CC (1986) First record of Monophyllus from Montserrat, West Indies. Mammalia 50: 269-271.

Pine RH, Bishop IR, Jackson RL (1970) Preliminary list of mammals of the Xavantina/Cachimbo Expedition (central Brazil). Transactions of the Royal Society of Tropical Medicine and Hygiene 64: 668-70. https://doi.org/10.1016/0035-9203(70)90003-9

Rojas D, Warsi OM, Dávalos LM (2016) Bats (Chiroptera: Noctilionoidea) challenge a recent origin of extant neotropical diversity. Systematic Biology 65: 432-448. https://doi. org/10.1093/sysbio/syw011

Sáez AG, Lozano E (2005) Cryptic species: as we discover more examples of species that are morphologically indistinguishable, we need to ask why and how they exist. Nature 433: 111. https://doi.org/10.1038/433111a

Sikes RS, Animal Care and Use Committee of the American Society of Mammalogists (2016) 2016 guidelines of the American Society of Mammalogists for the use of wild mammals in research and education. Journal of Mammalogy 97: 663-688. https://doi.org/10.1093/ jmammal/gyw078

Simmons NB (2005) Order Chiroptera. In: Wilson DE, Reeder DM (Eds) Mammal species of the World: a taxonomic and geographic reference. Johns Hopkins University Press, Baltimore, 312-529.

Simmons NB, Voss RS (1998) The mammals of Paracou, French Guiana: a Neotropical lowland rainforest fauna, Part 1, bats. Bulletin of the American Museum of Natural History 237: 1-219.

Straney DO (1984) The nasal bones of Chiroderma (Phyllostomidae). Journal of Mammalogy 65: 163-165. https://doi.org/10.2307/1381222

Taddei VA, Lim BK (2010) A new species of Chiroderma (Chiroptera, Phyllostomidae) from Northeastern Brazil. Brazilian Journal of Biology 70: 381-386. https://doi.org/10.1590/ S1519-69842010000200021

Tamura K, Stecher G, Peterson D, Filipski A, Kumar S (2013) MEGA6: Molecular Evolutionary Genetics Analysis version 6.0. Molecular Biology and Evolution 30: 2725-2729. https://doi.org/10.1093/molbev/mst197

Turcios-Casco MA, Medina-Fitoria A, Estrada-Andino N (2020) Northernmost record of Chiroderma trinitatum (Chiroptera, Phyllostomidae) in Latin America, with distributional comments. Caribbean Journal of Science 50: 9-15. https://doi.org/10.18475/cjos.v50i1.a2

Timm RM, LaVal RK (1998) A field key to the bats of Costa Rica. Occasional Publication Series, Center for Latin American Studies, University of Kansas 22: 1-30.

Webster WD, Fugler CM (1984) Lista de quiropteros de las regiones nortenas de Bolivia. Comunicaciónes del Museo Nacional de Historia Natural (La Paz) 3:13-19.

Voss RS, Emmons LH (1996) Mammalian diversity in Neotropical lowland rainforests: a preliminary assessment. Bulletin of the American Museum of Natural History 230: 1-115. 


\section{Appendix I}

Tissue samples of Chiroderma used in the cytochrome c oxidase subunit 1 analysis.

\begin{tabular}{|c|c|c|c|c|}
\hline Sample ID & Species & GenBank & Country & State/Department \\
\hline ROM 111114 & Chiroderma doriae & JF448016 & Brazil & Sao Paulo \\
\hline ROM 111141 & Chiroderma doriae & JF446371 & Brazil & Sao Paulo \\
\hline ROM 111149 & Chiroderma doriae & JF446373 & Brazil & Sao Paulo \\
\hline \multirow[t]{3}{*}{ ROM 111163} & Chiroderma doriae & JF446372 & Brazil & Sao Paulo \\
\hline & Chiroderma villosum & KT236232 & Brazil & Espirito Santo \\
\hline & Chiroderma villosum & KT236233 & Brazil & Espirito Santo \\
\hline ROM 105191 & Chiroderma trinitatum & JF448017 & Ecuador & Napo \\
\hline ROM 105230 & Chiroderma trinitatum & JF448810 & Ecuador & Napo \\
\hline ROM 105243 & Chiroderma trinitatum & JF448806 & Ecuador & Napo \\
\hline ROM 105253 & Chiroderma trinitatum & JF448805 & Ecuador & Napo \\
\hline ROM 105581 & Chiroderma trinitatum & JF448811 & Ecuador & Napo \\
\hline ROM 105685 & Chiroderma trinitatum & JF448807 & Ecuador & Napo \\
\hline ROM 105718 & Chiroderma trinitatum & JF448809 & Ecuador & Napo \\
\hline ROM 105766 & Chiroderma trinitatum & JF448808 & Ecuador & Napo \\
\hline ROM 106342 & Chiroderma trinitatum & JF448812 & Ecuador & Napo \\
\hline ROM F40504 & Chiroderma trinitatum & JF448813 & Ecuador & Napo \\
\hline ROM 104448 & Chiroderma villosum & JF448818 & Ecuador & Napo \\
\hline ROM 104540 & Chiroderma villosum & JF448829 & Ecuador & Napo \\
\hline ROM 104541 & Chiroderma villosum & JF448814 & Ecuador & Napo \\
\hline ROM 104549 & Chiroderma villosum & JF448828 & Ecuador & Napo \\
\hline ROM 105244 & Chiroderma villosum & JF448815 & Ecuador & Napo \\
\hline ROM 105254 & Chiroderma villosum & JF448816 & Ecuador & Napo \\
\hline ROM 105267 & Chiroderma villosum & JF448826 & Ecuador & Napo \\
\hline ROM 105361 & Chiroderma villosum & JF448825 & Ecuador & Napo \\
\hline ROM 105540 & Chiroderma villosum & JF448824 & Ecuador & Napo \\
\hline ROM 105587 & Chiroderma villosum & JF448830 & Ecuador & Napo \\
\hline ROM 105719 & Chiroderma villosum & JF448822 & Ecuador & Napo \\
\hline ROM 105720 & Chiroderma villosum & JF448821 & Ecuador & Napo \\
\hline ROM 105721 & Chiroderma villosum & JF448820 & Ecuador & Napo \\
\hline ROM 105928 & Chiroderma villosum & JF448817 & Ecuador & Napo \\
\hline ROM 105968 & Chiroderma villosum & JF448819 & Ecuador & Napo \\
\hline ROM F37400 & Chiroderma villosum & JF448827 & Ecuador & Napo \\
\hline ROM F37774 & Chiroderma villosum & JF448823 & Ecuador & Napo \\
\hline \multirow[t]{2}{*}{ ROM 101245} & Chiroderma villosum & JF446499 & El Salvador & Ahuachapan \\
\hline & Chiroderma villosum & KU295490 & French Guiana & \\
\hline ROM 99703 & Chiroderma salvini & JF446777 & Guatemala & El Progreso \\
\hline ROM 103486 & Chiroderma trinitatum & JF454560 & Guyana & Upper Demerara-Berbice \\
\hline ROM 103503 & Chiroderma trinitatum & JF454561 & Guyana & Upper Demerara-Berbice \\
\hline ROM 103504 & Chiroderma trinitatum & MN714876 & Guyana & Upper Demerara-Berbice \\
\hline ROM 103505 & Chiroderma trinitatum & JF454562 & Guyana & Upper Demerara-Berbice \\
\hline ROM 107205 & Chiroderma trinitatum & EF080285 & Guyana & Potaro-Siparuni \\
\hline ROM 107419 & Chiroderma trinitatum & EF080286 & Guyana & Potaro-Siparuni \\
\hline ROM 107476 & Chiroderma trinitatum & MN714877 & Guyana & Potaro-Siparuni \\
\hline ROM 108144 & Chiroderma trinitatum & JF454552 & Guyana & Cuyuni-Mazaruni \\
\hline ROM 108244 & Chiroderma trinitatum & JF454559 & Guyana & Cuyuni-Mazaruni \\
\hline
\end{tabular}




\begin{tabular}{|c|c|c|c|c|}
\hline Sample ID & Species & GenBank & Country & State/Department \\
\hline ROM 108463 & Chiroderma trinitatum & JF454544 & Guyana & Potaro-Siparuni \\
\hline ROM 108554 & Chiroderma trinitatum & JF454545 & Guyana & Potaro-Siparuni \\
\hline ROM 108587 & Chiroderma trinitatum & JF454555 & Guyana & Potaro-Siparuni \\
\hline ROM 108588 & Chiroderma trinitatum & JF454554 & Guyana & Potaro-Siparuni \\
\hline ROM 108714 & Chiroderma trinitatum & EF080287 & Guyana & Potaro-Siparuni \\
\hline ROM 108763 & Chiroderma trinitatum & MN714878 & Guyana & Potaro-Siparuni \\
\hline ROM 108889 & Chiroderma trinitatum & EF080288 & Guyana & Potaro-Siparuni \\
\hline ROM 108950 & Chiroderma trinitatum & JF454557 & Guyana & Potaro-Siparuni \\
\hline ROM 108993 & Chiroderma trinitatum & JF454556 & Guyana & Potaro-Siparuni \\
\hline ROM 109026 & Chiroderma trinitatum & MN714879 & Guyana & Potaro-Siparuni \\
\hline ROM 109195 & Chiroderma trinitatum & JF454558 & Guyana & Potaro-Siparuni \\
\hline ROM 109271 & Chiroderma trinitatum & JF454553 & Guyana & Potaro-Siparuni \\
\hline ROM 109333 & Chiroderma trinitatum & JF454542 & Guyana & Potaro-Siparuni \\
\hline ROM 111627 & Chiroderma trinitatum & JF454543 & Guyana & Potaro-Siparuni \\
\hline ROM 111809 & Chiroderma trinitatum & JF454547 & Guyana & Potaro-Siparuni \\
\hline ROM 111844 & Chiroderma trinitatum & MN714880 & Guyana & Potaro-Siparuni \\
\hline ROM 111884 & Chiroderma trinitatum & JF454546 & Guyana & Potaro-Siparuni \\
\hline ROM 111946 & Chiroderma trinitatum & JF454548 & Guyana & Potaro-Siparuni \\
\hline ROM 115807 & Chiroderma trinitatum & JF454550 & Guyana & Potaro-Siparuni \\
\hline ROM 116630 & Chiroderma trinitatum & JF454549 & Guyana & Potaro-Siparuni \\
\hline ROM 118996 & Chiroderma trinitatum & JF454551 & Guyana & Upper Takutu-Upper Essequibo \\
\hline ROM 121975 & Chiroderma trinitatum & MN714881 & Guyana & Potario-Siparuni \\
\hline ROM 125124 & Chiroderma trinitatum & MN714882 & Guyana & Potaro-Siparuni \\
\hline ROM 103214 & Chiroderma villosum & JF454584 & Guyana & Upper Takutu-Upper Essequibo \\
\hline ROM 103331 & Chiroderma villosum & JF454585 & Guyana & Upper Takutu-Upper Essequibo \\
\hline ROM 106644 & Chiroderma villosum & JF454566 & Guyana & Upper Takutu-Upper Essequibo \\
\hline ROM 107111 & Chiroderma villosum & EF080290 & Guyana & Potaro-Siparuni \\
\hline ROM 107112 & Chiroderma villosum & EF080291 & Guyana & Potaro-Siparuni \\
\hline ROM 107394 & Chiroderma villosum & EF080292 & Guyana & Potaro-Siparuni \\
\hline ROM 108203 & Chiroderma villosum & JF454565 & Guyana & Cuyuni-Mazaruni \\
\hline ROM 108219 & Chiroderma villosum & JF454564 & Guyana & Cuyuni-Mazaruni \\
\hline ROM 108764 & Chiroderma villosum & JF454571 & Guyana & Potaro-Siparuni \\
\hline ROM 108765 & Chiroderma villosum & JF454570 & Guyana & Potaro-Siparuni \\
\hline ROM 108843 & Chiroderma villosum & EF080289 & Guyana & Potaro-Siparuni \\
\hline ROM 108998 & Chiroderma villosum & JF454573 & Guyana & Potaro-Siparuni \\
\hline ROM 109138 & Chiroderma villosum & JF454572 & Guyana & Potaro-Siparuni \\
\hline ROM 109175 & Chiroderma villosum & JF454569 & Guyana & Potaro-Siparuni \\
\hline ROM 109221 & Chiroderma villosum & JF454568 & Guyana & Potaro-Siparuni \\
\hline ROM 109270 & Chiroderma villosum & JF454567 & Guyana & Potaro-Siparuni \\
\hline ROM 109307 & Chiroderma villosum & JF454583 & Guyana & Potaro-Siparuni \\
\hline ROM 109308 & Chiroderma villosum & JF454582 & Guyana & Potaro-Siparuni \\
\hline ROM 109337 & Chiroderma villosum & JF454581 & Guyana & Potaro-Siparuni \\
\hline ROM 111628 & Chiroderma villosum & EF080293 & Guyana & Potaro-Siparuni \\
\hline ROM 111629 & Chiroderma villosum & JF459119 & Guyana & Potaro-Siparuni \\
\hline ROM 111754 & Chiroderma villosum & JF454580 & Guyana & Potaro-Siparuni \\
\hline ROM 111768 & Chiroderma villosum & JF454579 & Guyana & Potaro-Siparuni \\
\hline ROM 111769 & Chiroderma villosum & JF454578 & Guyana & Potaro-Siparuni \\
\hline ROM 111770 & Chiroderma villosum & JF454577 & Guyana & Potaro-Siparuni \\
\hline ROM 111788 & Chiroderma villosum & JF454576 & Guyana & Potaro-Siparuni \\
\hline ROM 111836 & Chiroderma villosum & JF454575 & Guyana & Potaro-Siparuni \\
\hline
\end{tabular}




\begin{tabular}{|c|c|c|c|c|}
\hline Sample ID & Species & GenBank & Country & State/Department \\
\hline ROM 111845 & Chiroderma villosum & JF454574 & Guyana & Potaro-Siparuni \\
\hline ROM 119167 & Chiroderma villosum & MN714883 & Guyana & Upper Takutu-Upper Essequibo \\
\hline ROM 119230 & Chiroderma villosum & JF454586 & Guyana & Upper Takutu-Upper Essequibo \\
\hline ROM 122481 & Chiroderma villosum & MN714884 & Guyana & Potaro-Siparuni \\
\hline ROM 98850 & Chiroderma villosum & JF454563 & Guyana & Barima-Waini \\
\hline ROM 125179 & Chiroderma villosum & MN714885 & Guyana & East Berbice-Corentyne \\
\hline ROM F38952 & Chiroderma villosum & MN714886 & Guyana & Potaro-Siparuni \\
\hline ROM 98702 & Uroderma bilobatum & JF435925 & Guyana & Barima-Waini \\
\hline ROM 96536 & Chiroderma villosum & JF448018 & Mexico & Campeche \\
\hline ROM FN30654 & Chiroderma villosum & JF447242 & Mexico & Campeche \\
\hline ROM 104342 & Chiroderma gorgasi & MN714901 & Panama & Darien \\
\hline ROM 104352 & Chiroderma villosum & JF447405 & Panama & Darien \\
\hline ROM F38210 & Chiroderma villosum & JF447406 & Panama & Darien \\
\hline ROM 122084 & Chiroderma trinitatum & MN714887 & Peru & Loreto \\
\hline ROM 122137 & Chiroderma trinitatum & MN714888 & Peru & Loreto \\
\hline ROM 122149 & Chiroderma trinitatum & MN714889 & Peru & Loreto \\
\hline ROM 122165 & Chiroderma villosum & MN714890 & Peru & Loreto \\
\hline ROM 122260 & Chiroderma villosum & MN714891 & Peru & Loreto \\
\hline ROM 125567 & Chiroderma villosum & MN714892 & Peru & Tumbes \\
\hline ROM 126002 & Chiroderma improvisum & MN714893 & Nevis & Saint Thomas Lowland Parish \\
\hline ROM 114170 & Chiroderma trinitatum & JF447622 & Suriname & Brokopondo \\
\hline ROM 114213 & Chiroderma trinitatum & JF447625 & Suriname & Brokopondo \\
\hline ROM 114233 & Chiroderma trinitatum & JF447623 & Suriname & Brokopondo \\
\hline ROM 114234 & Chiroderma trinitatum & JF447624 & Suriname & Brokopondo \\
\hline ROM 117003 & Chiroderma trinitatum & JF447627 & Suriname & Sipaliwini \\
\hline ROM 117003 & Chiroderma trinitatum & MN714894 & Suriname & Sipaliwini \\
\hline ROM 117027 & Chiroderma trinitatum & JF447626 & Suriname & Sipaliwini \\
\hline ROM 117083 & Chiroderma trinitatum & JF447628 & Suriname & Sipaliwini \\
\hline ROM 117376 & Chiroderma trinitatum & EU096695 & Suriname & Sipaliwini \\
\hline ROM 117555 & Chiroderma trinitatum & EU096696 & Suriname & Sipaliwini \\
\hline ROM 120098 & Chiroderma trinitatum & MN714895 & Suriname & Sipaliwini \\
\hline ROM 120168 & Chiroderma trinitatum & HQ545629 & Suriname & Sipaliwini \\
\hline ROM 120225 & Chiroderma trinitatum & HQ545678 & Suriname & Sipaliwini \\
\hline ROM 120384 & Chiroderma trinitatum & HQ919736 & Suriname & Sipaliwini \\
\hline ROM 114212 & Chiroderma villosum & JF447630 & Suriname & Brokopondo \\
\hline ROM 114228 & Chiroderma villosum & JF447631 & Suriname & Brokopondo \\
\hline ROM 117119 & Chiroderma villosum & JF447629 & Suriname & Sipaliwini \\
\hline ROM 117375 & Chiroderma villosum & EU096697 & Suriname & Sipaliwini \\
\hline ROM 120226 & Chiroderma villosum & HQ545679 & Suriname & Sipaliwini \\
\hline ROM 120239 & Chiroderma villosum & HQ545445 & Suriname & Sipaliwini \\
\hline ROM 120240 & Chiroderma villosum & HQ545446 & Suriname & Sipaliwini \\
\hline ROM 120354 & Chiroderma villosum & MN714896 & Suriname & Sipaliwini \\
\hline ROM 120364 & Chiroderma villosum & HQ919717 & Suriname & Sipaliwini \\
\hline ROM 121027 & Chiroderma villosum & MN714897 & Suriname & Sipaliwini \\
\hline ROM 121117 & Chiroderma villosum & MN714898 & Suriname & Sipaliwini \\
\hline ROM 126174 & Chiroderma villosum & MN714899 & Suriname & Para \\
\hline ROM 113919 & Platyrrbinus incarum & JF435616 & Suriname & Brokopondo \\
\hline ACUNHC 393 & Chiroderma villosum & MN714900 & Venezuela & Amazonas \\
\hline
\end{tabular}




\section{Appendix 2}

Tissue samples of Chiroderma used in the cytochrome b analysis.

\begin{tabular}{lcccc}
\hline \multicolumn{1}{c}{ Sample ID } & Species & GenBank & Country & State/Province \\
\hline UNESP 16506 & Chiroderma doriae & L28937 & Brazil & Sao Paulo \\
TK 16379 & Chiroderma doriae & AY169958 & Brazil & \\
TK 15713 & Chiroderma improvisum & L28938 & Montserrat & St. Anthony \\
TK 25052 & Chiroderma villosum & DQ312414 & Trinidad & St. George \\
FMNH 174652 & Chiroderma villosum & FJ154121 & Peru & Madre de Dios \\
TK 17627 & Platyrrhinus helleri & L28940 & Suriname & Marowijne \\
TK 25256 & Uroderma bilobatum & L28941 & Trinidad & St. George \\
TK 22581 & Chiroderma salvini & L28939 & Panama & Darien \\
TK 25211 & Chiroderma trinitatum & DQ312413 & Trinidad & St. George \\
ASK 7799 & Chiroderma villosum & JF442196 & Ecuador & Orellana \\
ASK 7667 & Chiroderma villosum & JF442139 & Ecuador & Napo \\
MN 36375 & Chiroderma villosum & DQ903823 & Brazil & \\
SK-Bat-61 & Chiroderma improvisum & JQ915203 & Saint Kitts & \\
ROM 104342 & Chiroderma gorgasi & MN714902 & Panama & Darien \\
\hline
\end{tabular}

\section{Appendix 3}

Specimens of Chiroderma examined morphologically. Vouchers examined are arranged alphabetically by species and country. See "Material and Methods" for collection acronyms.

Chiroderma doriae - Brazil: São Paulo - ROM 111163, ROM 111141, ROM 111114 , ROM 111149.

Chiroderma improvisum - Montserrat: St. Anthony Parsish - TTU 31403; St. Kitts and Nevis: Barnes Ghaut - ROM 126002.

Chiroderma salvini - El Salvador: Morazan - ROM 83365, ROM 85948, Santa Ana ROM 101526; Guatemala: El Progreso - ROM 99703; Panama: Darien - ROM 78472, ROM 91194.

Chiroderma trinitatum gorgasi - Colombia: Valle del Cauca - USNM 483763, USNM 483765, Antioquia - USNM 499478, USNM 499476; Panama: Bocas Del Toro - USNM 319498, USNM 335295, Darien - FMNH 128132, ROM 104342, USNM 309901, USNM 309903-holotype, San Blas - USNM 309905.

Chiroderma trinitatum trinitatum - Colombia: Vaupes - ROM 45276, ROM 45278, ROM 45280, ROM 45281, ROM 45284, Putumayo - ROM 63236, ROM 63237, ROM 63238; Ecuador: Napo - ROM 105191, ROM 105243, ROM 105253, ROM 105685, ROM 105766, ROM 106342; Guyana: Cuyuni-Mazaruni - ROM 108144, Demerara-Berbice - ROM 57392, ROM 103486, ROM 103503, Upper, Potaro-Siparuni - ROM 107205, ROM 107419, ROM 107476, ROM 108463, ROM 108554, ROM 108587, ROM 108714, ROM 108763, ROM ROM 108889, 
ROM 108950, ROM 108993, ROM 109195, ROM 109333, ROM 111627, ROM 111809, ROM 111884, ROM 111946, ROM 115807, ROM 116630; Suriname: Brokopondo - ROM 114170, ROM 114213, ROM 114233, ROM 114234, Sipaliwini - ROM 117027, ROM 117376, ROM 120168, ROM 120225, ROM 120384; Trinidad: Saint Andrew County - AMNH 175325-holotype.

Chiroderma villosum - Bolivia: Carrasco - ROM 78471; Colombia: Choco - ROM 85849, Vaupes - ROM 44952, ROM 44953, ROM 44954, ROM 45243, ROM 45245, ROM 45246, ROM 45247, ROM 45249, ROM 45250, ROM 45251, ROM 45252, ROM 45253, ROM 45254, ROM 45255, ROM 45257; Ecuador: Napo - ROM 104448, ROM 104541, ROM 104549, ROM 105244, ROM 105254, ROM 105361, ROM 105720, ROM 105721); Guyana: Barima-Waini - ROM 98850, Potaro-Siparuni - ROM 107111, ROM 107112, ROM 107394, ROM 108219, ROM 108764, ROM 108843, ROM 108998, ROM 109138, ROM 109175, ROM 109221, ROM 109307, ROM 109308, ROM 109337, ROM 111628, ROM 111629, ROM 111754, ROM 111768, ROM 111769, ROM 111770, ROM 111788, ROM 111836, ROM 111845, ROM 122481, Upper Demerara-Berbice - ROM 60402, ROM 60423, Upper Takutu-Upper Essequibo - ROM 35614, ROM 103214, ROM 106644, ROM 119167, ROM 119230; Panama: Darien - ROM 104352; Suriname: Brokopondo - ROM 114212, Sipaliwini - ROM 117119, ROM 117375, ROM 120226, ROM 120239, ROM 120364, ROM 121027; Trinidad and Tobago: Nariva - ROM 124684, ROM 124691.

\section{Supplementary material I}

Maximum likelihood tree of cytochrome c oxidase subunit 1 gene for big-eyed bats Chiroderma as presented in Fig. 3, but expanded to show individuals

Authors: Burton K. Lim, Livia O. Loureiro, Guilherme S. T. Garbino

Data type: phylogenetic dendrogram

Copyright notice: This dataset is made available under the Open Database License (http://opendatacommons.org/licenses/odbl/1.0/). The Open Database License $(\mathrm{ODbL})$ is a license agreement intended to allow users to freely share, modify, and use this Dataset while maintaining this same freedom for others, provided that the original source and author(s) are credited.

Link: https://doi.org/10.3897/zookeys.918.48786.suppl1 


\section{Supplementary material 2}

Maximum parsimony tree of cytochrome c oxidase subunit 1 gene for Chiroderma. Bootstrap percentages show support at each node

Authors: Burton K. Lim, Livia O. Loureiro, Guilherme S. T. Garbino

Data type: phylogenetic dendrogram

Copyright notice: This dataset is made available under the Open Database License (http://opendatacommons.org/licenses/odbl/1.0/). The Open Database License $(\mathrm{ODbL})$ is a license agreement intended to allow users to freely share, modify, and use this Dataset while maintaining this same freedom for others, provided that the original source and author(s) are credited.

Link: https://doi.org/10.3897/zookeys.918.48786.suppl2

\section{Supplementary material 3}

Maximum likelihood tree of cytochrome b gene for Chiroderma. Bootstrap percentages show support at each node

Authors: Burton K. Lim, Livia O. Loureiro, Guilherme S. T. Garbino

Data type: phylogenetic dendrogram

Copyright notice: This dataset is made available under the Open Database License (http://opendatacommons.org/licenses/odbl/1.0/). The Open Database License $(\mathrm{ODbL})$ is a license agreement intended to allow users to freely share, modify, and use this Dataset while maintaining this same freedom for others, provided that the original source and author(s) are credited.

Link: https://doi.org/10.3897/zookeys.918.48786.suppl3

\section{Supplementary material 4}

Maximum parsimony tree of cytochrome b gene for Chiroderma. Bootstrap percentages show support at each node

Authors: Burton K. Lim, Livia O. Loureiro, Guilherme S. T. Garbino

Data type: phylogenetic dendrogram

Copyright notice: This dataset is made available under the Open Database License (http://opendatacommons.org/licenses/odbl/1.0/). The Open Database License $(\mathrm{ODbL})$ is a license agreement intended to allow users to freely share, modify, and use this Dataset while maintaining this same freedom for others, provided that the original source and author(s) are credited.

Link: https://doi.org/10.3897/zookeys.918.48786.suppl4 